\title{
Screening wheat genotypes for coleoptile length: A trait for drought tolerance
}

\author{
Md. Farhad ${ }^{1}$, Md. Abdul Hakim ${ }^{1}$, Md. Ashraful Alam ${ }^{1}$, N. C. D. Barma ${ }^{2}$ \\ ${ }^{1}$ Wheat Research Centre, BARI, Nashipur, Dinajpur-5200, Bangladesh \\ ${ }^{2}$ Regional Wheat Research Centre, BARI, Joydebpur, Gazipur-1701, Bangladesh
}

Email address:

farhadnabin@bari.gov.bd (Md. Farhad)

To cite this article:

Md. Farhad, Md. Abdul Hakim, Md. Ashraful Alam, N. C. D. Barma. Screening Wheat Genotypes for Coleoptile Length: A Trait for Drought Tolerance. American Journal of Agriculture and Forestry. Vol. 2, No. 6, 2014, pp. 237-245. doi: 10.11648/j.ajaf.20140206.11

\begin{abstract}
The study was conducted during Rabi season of 2013-14 at the Wheat Research Centre (WRC), Bangladesh Agricultural Research Institute (BARI), Dinajpur. Thirty wheat genotypes including local control BARI Gom 26 were evaluated in split-split plot design having two replications with irrigation in the main plot, seeding depth in a sub-plot and genotype was in sub-sub-plot. The main objective of this study was to evaluate new exotic lines against drought, with emphasis on coleoptile length under Bangladeshi conditions, and to identify drought tolerant germplasm. To measure potential coleoptile length (CL), disease free, healthy, uniform seeds were sown in wooden trays with sandy soil in a temperature controlled room at 200 degree days $\left(20^{\circ} \mathrm{c}\right.$ X 10 days). The genotypes were evaluated for yield, and yield components i.e., plant establishment, plant height $(\mathrm{cm})$, spikes per $\mathrm{m}^{2}$, grains per Spike, 1000-grain weight $(\mathrm{g})$ and visual grain quality. Selection of genotypes was based on Schneider's stress severity index (SSSI), yield under drought condition and coleoptiles length. Deep seeding over normal seeding had a significant effect on yield and the yield components, as did water stress. The interaction of the two factors showed that seeding depth causes more yield loss than irrigation. More traits showed significant relationships in deep seeding conditions than normal conditions, meaning that there is greater scope for screening wheat using sowing depth. Based on higher negative value of SSSI and higher yield in deep sowing conditions the genotypes G 16, G 13, G 12, G 24, G 2, G 18, G 19 and G 3 were primarily selected for drought tolerance and will be evaluated further for advanced studies. These genotypes also have longer coleoptiles ranging from 7.4 to $10.5 \mathrm{~cm}$.
\end{abstract}

Keywords: Wheat, Drought Tolerance, Deep Sowing, Coleoptile Length, Irrigation, Index

\section{Introduction}

Climate change in Bangladesh is expected to aggravate the situation along with the withdrawal of upstream water, resulting in increasing droughts and depletion of the water table. Crop production becomes impossible especially in drier northern and western regions of the country. Bangladesh already faces drought in the northwestern region [10] and it is expected that the moderately drought affected areas will become severely drought prone areas within the next two decades. The intensity and frequency of climatic hazards has brought to light the necessity for introducing stress tolerant varieties into breeding programs in Bangladesh, and for quick extension to growers. In addition, global climate change is negatively affecting crop yields under the current climate and is predicted to have a more severe impact on food production in future climate scenarios
[22].

Wheat (Triticum aestivum $\mathrm{L}$ ) is the second most important cereal crop in Bangladesh in respect of area and production cultivated in the winter season. However, due to light rainfall and scarcity of available irrigation facilities in the winter season, it suffers from soil moisture stress during the growing period. Being adapted to a wide range of moisture conditions, wheat is grown on more land area worldwide than any other crop, including in drought prone areas. In these marginal rain-fed environments where at least $60 \mathrm{~m}$ ha of wheat is grown, amount and distribution of rainfall are the predominant factors influencing yield variability [35]. Exposure of plants to drought led to a noticeable reduction in yield and yield contributing characters such as plant height, number of spikes per plant, total dry matter, number of seeds per spike, and 100- grain weight and grain yield [20]. There is an ever increasing interest in improving drought tolerance 
of wheat to attain a yield substantial enough to meet the increasing demand of a rapidly increasing population through breeding for drought tolerant and high yielding cultivars [54].

\subsection{Significance of Long Coleoptile}

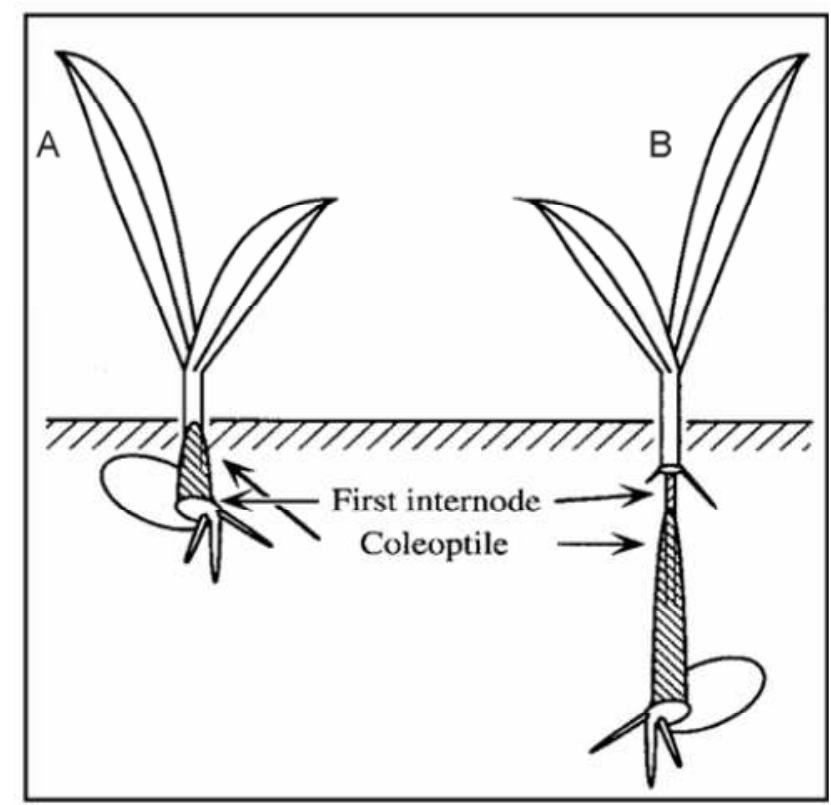

Fig 1. Schematic presentation of seedling growth under normal (A) and deep-seeding (B) conditions.

The coleoptile is an outer covering that protects the first leaf of the developing wheat plant as it pushes its way toward the surface of the soil during germination. If the coleoptile is shorter than the sowing depth, the first leaf must push through the soil and emerge in a dark environment. The longer it takes the first leaf to reach the surface, the more vulnerable the seedling is to soil crusting and diseases [21]. The coleoptile is essential for successful emergence and early plant vigour. Drought could promote the increase of Coleoptile Length (CL) and inhibit seedling height [21].

Wheat with long coleoptiles emerges with higher frequency than those with short coleoptiles especially when sown deep. [45, 46 and 47] When sown deep, wheat seedlings with short coleoptiles do emerge but much later and lack seedling vigour [19 and 47]. Deep sowing allows growers to exploit soil moisture lying below the drying topsoil and is an option considered by growers in Australia [11]. In some genotypes, shoots are able to reach the soil surface from the deep soil by elongating basal organs, e.g. coleoptile and first internode in wheat and barley [64] (Figure 1). Deeper sowing also assists in reducing removal of seeds by birds and rodents [8] and in avoiding phytotoxicity associated with some pre-emergent herbicides [40]. Deep sown seedlings with short coleoptile have smaller relative growth rates and slower leaf area development resulting in smaller leaf area early in the season which reduces the competitiveness of wheat crop against weeds and increases water loss through evaporation from the soil surface thus reducing crop water use efficiency, biomass and finally yield [30]. Deep seed placement and reduced coleoptile elongation in the predominantly hot soil can have a potentially devastating impact on stand establishment [55]. It was reported that seed size had little impact on coleoptiles lengths in barley but not in wheat and oats [9]. Studies have demonstrated a strong association between coleoptiles length and seedling emergence with shallow [14] and deep sowing $[19,29,32,50$ and 61]. Surveys of Australian farmers' fields show that grain yield is reduced by a minimum $10 \%$ when short coleoptiles wheats are sown deeper than $5 \mathrm{~cm}$ [49]. Reduced establishment and lower grain yields associated with deep sowing have been reported for shorter coleoptile wheats [31, 32, 37, 44 and 50]. A recombinant inbred line (RIL) population showed considerable variation, normal distribution and transgressive segregation for CL under field and controlled environment conditions [26].

Wheat with longer coleoptiles emerged sooner, produced more plants and had greater early vigour particularly with deep sowing. Semi dwarf wheat has CL $30-40 \%$ shorter than non-semi dwarf wheat [2]. Selection for CL usually occurs in either a greenhouse in controlled environment condition or in field plots through deep planting. Selection under the controlled conditions of a growth chamber has the advantage of being quicker, cheaper and possibly more effective for increasing CL than field selection [25]. Selection of wheat cultivars with long coleoptile is an important component of improving emergence, weed suppression and grain yield in low rainfall regions. This would be useful tool in managing climate variability and would assist wheat growers to sow closer to the optimum sowing time in situations where moisture is present at depth but not on the soil surface. Considerable genetic variation has been observed for this trait and several studies have reported relationship between $\mathrm{CL}$ and seedling emergence and subsequent effect on early growth, biomass and grain yield.

\section{Materials and Methods}

The experimental material of the study was consisted of thirty genotypes of spring wheat (Triticum aestivum L.) including local control variety BARI Gom 26, collected from "4th CSISA drought yield trial 2011-12" [63]. To measure potential CL of the materials, disease free, healthy uniform seeds were sown in wooden trays with sandy soil in a temperature controlled room at 200 degree days $\left(20^{\circ} \mathrm{c}\right.$ X 10 days). The field study was conducted at the experimental field of the Wheat Research Centre (WRC), Bangladesh Agricultural Research Institute (BARI), Dinajpur during 2013-14 cropping season. The genotypes were grown in rain fed, irrigated, deep seeding (around $5 \mathrm{~cm}$ below the soil surface) and normal seeding conditions (around $10 \mathrm{~cm}$ below the soil surface). Three irrigations were applied in the irrigated plots whereas no irrigation was applied in non irrigated plots to induce water stress. Root depths were between $5 \mathrm{~cm}$ below soil surface and around $10 \mathrm{~cm}$ below soil surface. The experiment was laid out in split-split plot 
design with two replications with irrigation in the main plot, seeding depth in the sub-plot and genotype in the sub-subplot. Randomization for the trial was generated by Cropstat 7.2 software [23]. Seeds were sown continuously in $2.5 \mathrm{~m}$ long, 4-row plots with a row spacing of $20 \mathrm{~cm}$ with 1 meter between replicates. A two meter distance was maintained between the irrigated and non irrigated plots to control the unexpected water movement from irrigated plots to non irrigated plots. Recommended fertilizers and cultivation practices were followed in every plot. Data were recorded on yield $(\mathrm{Y})$ and other yield contributing characters e.g., plant establishment (EPP), plant height in $\mathrm{cm}(\mathrm{PH})$, number of spikes per $\mathrm{m}^{2}$ (SPN), grains per Spike (GPS) and 1000-grain weight in grams (TGW). At maturity, the whole plot was harvested to estimate grain yield measured in $\mathrm{kg}$ per hectare. Data were analyzed by ANOVA using Cropstat 7.2 software. A correlation matrix was calculated by Mltibase_2015 add-in to MS Excel [36]. Duncan's multiple range test was performed by using DSAASTAT add-in to MS Excel [41].

Selection of genotypes was based on index proposed by a modified formula of Stress Susceptibility Index (SSI) [15]. According to the formula (Yi)s denote the yield of the ith genotype under stress, (Yi)ns the yield of the ith genotype under nonstress (i.e., irrigated) conditions and Ys and Yns is the mean yields of all genotypes evaluated under stress and nonstress conditions, respectively. SSI is expressed by $S S I=$ $\frac{1-\frac{(Y i) s}{(Y i) n s}}{S I}$, SI, the stress intensity is estimated as $S I=1-\frac{Y s}{Y n s}$. Lower SSI values indicate lower differences in yield across stress levels, in other words, more resistance to drought. The modified formula for Schneider's stress severity index [51,
52] is $S S S I=\left(1-\frac{(Y i) s}{(Y i) n s}\right)-\left(1-\frac{Y s}{Y n s}\right)$. The SSSI estimates the relative tolerance for yield reduction of a genotype relative to the population mean reduction in grain yield response due to stress. Selections based on these indices were carried out by many authors $[18,28,39,42,43,52,53$, and 57].

\section{Results and Discussion}

The average coleoptiles lengths of the 30 genotypes varied in range, presented in table 1 . The CL varied from $3.5 \mathrm{~cm}$ (G6) to $12.10 \mathrm{~cm}$ (G12) in different genotypes and the highest mean CL was $10.9 \mathrm{~cm}$ in G 25. The mean CL was recorded above $10 \mathrm{~cm}$ in G26, G30, G12 and G20, and 5 genotypes (G22, G 11, G 17, G 24 and G 21) were produced from 9.0 to $9.9 \mathrm{~cm}$. Mean CL from $8.2 \mathrm{~cm}$ to $8.8 \mathrm{~cm}$ was in 8 genotypes. Another group having 7 to $7.8 \mathrm{~cm} \mathrm{CL}$ consist of 8 genotypes. The remaining 4 genotypes vary for mean CL between 5.5 and $6.8 \mathrm{~cm}$. CL variation among the CIMMYT lines in this collection was very narrow with the majority having a CL between $7-10.9 \mathrm{~cm}$. This narrow variation is probably due to the semi-dwarf nature of all the collected lines and/or due to a common genetic background and having been previously selected from $4^{\text {th }}$ CSISA drought trial. A number of non-genetic factors have been reported to affect seedling vigour and CL including variation in grain size [27, 13], grain positions in the ear [56] and the environment from which the grain was harvested [37, 44]. Seed source is obviously a very important determinant of CL [24].

Table 1. Average CL with range of 30 genotypes.

\begin{tabular}{cclcccccc}
\hline Genotype & Average CL $(\mathbf{c m})$ & Range $(\mathbf{c m})$ & Genotype & Average CL (cm) & Range (cm) & Genotype & Average CL (cm) & Range (cm) \\
\hline G-1 & 7.5 & $5.5-9.5$ & G-11 & 9.8 & $8.8-10.2$ & G-21 & 9.3 & $6.7-10.8$ \\
G-2 & 8.2 & $6.1-11.0$ & G-12 & 10.5 & $6.2-12.1$ & G-22 & 9.9 & $7.2-11.5$ \\
G-3 & 7.5 & $5.0-10.5$ & G-13 & 7.4 & $5.2-11.5$ & G-23 & 6.1 & $4.9-8.1$ \\
G-4 & 7.6 & $7.1-7.9$ & G-14 & 7.7 & $5.9-9.5$ & G-24 & 9.5 & $8.0-10.9$ \\
G-5 & 7.8 & $5.8-9.6$ & G-15 & 8.5 & $7.0-10.5$ & G-25 & 10.9 & $9.0-11.9$ \\
G-6 & 5.5 & $3.5-9.5$ & G-16 & 8.7 & $6.9-11.5$ & G-26 & 10.8 & $10.1-11.3$ \\
G-7 & 8.5 & $5.0-11.4$ & G-17 & 9.8 & $8.5-11.0$ & G-27 & 7.3 & $5.9-10.1$ \\
G-8 & 8.8 & $6.6-12.0$ & G-18 & 8.7 & $7.5-10.6$ & G-28 & 6.8 & $5.2-9.3$ \\
G-9 & 6.8 & $5.4-9.0$ & G-19 & 8.6 & $6.2-10.8$ & G-29 & 7.0 & $5.0-9.0$ \\
G-10 & 8.6 & $7.0-10.8$ & G-20 & 10.2 & $8.3-11.6$ & G-30 & 10.8 & $9.0-11.6$ \\
\hline
\end{tabular}

Table 2. Analysis of variance and coefficient of variation (CV) of each trait with different treatments in the field condition.

\begin{tabular}{|c|c|c|c|c|c|c|c|}
\hline \multirow{2}{*}{ Variation Source } & \multirow{2}{*}{ df } & \multicolumn{6}{|c|}{ Mean sum of squares } \\
\hline & & EPP & PH & SPN & GPS & TGW & $\mathbf{Y}$ \\
\hline Sowing depth (D) & 1 & $111208 * *$ & $817.705 * *$ & $656993 * *$ & $5219.2 * *$ & $136.33 * *$ & $77535400 * *$ \\
\hline Irrigation (IR) & 1 & 291.233 & 24.7042 & $187042 * *$ & $448.814 * *$ & 3.37542 & $100255000 * *$ \\
\hline D X IR & 1 & 304.601 & 30.1041 & $8449.07 *$ & 52.8282 & 13.1552 & 1368520 \\
\hline Genotype (G) & 29 & $337.558 * *$ & 41.6323 & $4080.67 * *$ & $83.695 * *$ & $26.6389 * *$ & $2345680 * *$ \\
\hline IR X G & 29 & 121.021 & 44.1956 & $5408.37 * *$ & 43.8669 & 12.3041 & $951139 * *$ \\
\hline $\mathrm{D} \times \mathrm{G}$ & 29 & $460.024 * *$ & 53.6955 & $5599.47 * *$ & $66.3746 * *$ & 9.84239 & $1724130 * *$ \\
\hline $\mathrm{CV}$ & & 18.5 & 7.5 & 14.9 & 10.4 & 9.1 & 14.5 \\
\hline
\end{tabular}

The mean sums of squares for the characters studied are presented in table 2. The mean sums of squares due to genotypes were significant for five characters studied while PH shows no significance for genotypes. The mean sum of squares suggests that the genotypes selected were genetically variable and a considerable amount of variability existed among them. This indicates selection for different quantitative characters for wheat improvement. These 
findings are in accordance with the findings of [3, 6 and 12] who also observed significant variability in wheat germplasm. Analysis of variance also revealed significant differences between treatments and among the genotypes. All the traits studied varied significantly for sowing depth while only SPN, GPS and Y showed a significant variation for irrigation. The sowing depth $\times$ genotype interactions were also significant for all the characters except PH and TGW. On the other hand Irrigation $\mathrm{X}$ Genotype interaction is significant for SPN and Y. This interaction revealed that genotypes performed inconsistently over the stress conditions. This significant variation in water stress conditions may serve as good indicator of drought tolerance.

The correlation coefficients of yield and yield contributing characters indicated some significant relation exist among the character studied. More traits showed significant relationship in deep seeding condition than normal condition, meaning that there is greater scope for screening wheat using sowing depth. CL showed a non-significant relationship except with number of spikes in irrigated deep seeding condition. As in [4 and 16] we found that plant height and
CL were not significantly correlated. There were no differences in the mean plant height for entries with coleoptiles longer than $90 \mathrm{~mm}$ in wheat as in [34]. They also indicated that coleoptiles longer than $90 \mathrm{~mm}$ showed no advantage for emergence from deep planting and might even have a negative effect. Again, it was also found that thousand kernel weight did not affect emergence on any days after planting nor was it associated with plant height at maturity [34]. It was revealed that wheat seedling emergence did not have linear relationship with CL as many other factors have been implicated in the process [48, 7 and 38]. Emergence and $\mathrm{CL}$ is reported to be influenced both by genetic background and environmental factors including soil texture, seed-zone water content, temperature, light penetration, and crop residue [58]. As we do not know the nature of dwarfing genes in the world collection, these could possibly be gibberellic acid (GA) sensitive genotypes that are reported to have no adverse effect on CL but reduce plant height, or possibly have favorable alleles for $\mathrm{CL}$ in semi-dwarf background [60].

Table 3. Simple Correlation coefficient between yield and the traits associated with yield.

Table 3a. Correlation Coefficient Matrix for normal sowing in irrigated and non-irrigated condition

\begin{tabular}{llllllll}
\hline & CL & EPP & PH & SPN & G & TGW \\
\hline CL & & 0.18 & -0.04 & 0.30 & -0.07 & -0.01 \\
EPP & 0.01 & & 0.34 & 0.31 & -0.25 & -0.23 \\
PH & -0.09 & 0.23 & 0.17 & 0.15 & -0.23 \\
SPN & -0.28 & 0.09 & 0.28 & & $-0.41^{*}$ & -0.23 \\
GPS & 0.12 & -0.34 & 0.02 & 0.12 & & 0.14 \\
TGW & 0.15 & -0.24 & -0.26 & -0.25 & 0.10 & 0.02 \\
Y & 0.22 & -0.08 & 0.19 & 0.16 & 0.25 & -0.06 \\
\hline
\end{tabular}

Parentheses are the $r^{2}$ of non-irrigated condition

Table 3b. Correlation Coefficient Matrix for deep sowing in irrigated and non-irrigated condition

\begin{tabular}{lllllll}
\hline & CL & EPP & PH & SPN & GPS & TGW \\
\hline CL & & -0.09 & 0.25 & $0.43^{*}$ & -0.18 & -0.01 \\
EPP & -0.11 & & 0.21 & 0.23 & -0.24 & -0.10 \\
PH & -0.30 & 0.28 & & $0.47 * *$ & 0.09 & -0.08 \\
SPN & -0.19 & 0.26 & $0.57 * *$ & & -0.09 & -0.09 \\
GPS & -0.06 & -0.32 & $-0.46^{* *}$ & -0.32 & $-0.55^{* *}$ & $0.68^{* *}$ \\
TGW & -0.27 & -0.04 & 0.23 & 0.21 & $-0.36^{*}$ & -0.25 \\
Y & -0.15 & 0.32 & $0.36^{*}$ & $0.58^{* *}$ & -0.12 & -0.14 \\
\hline
\end{tabular}

Parentheses are the $r^{2}$ of non-irrigated condition

Table 4. Mean effect of depth of seeding on yield and yield contributing characters of wheat.

\begin{tabular}{lllllll}
\hline Treatment & EPP & PH & SPN & GPS & TGW \\
\hline Normal Seeding & 78 & 97.4 & 328 & 49 & 46.11 \\
Deep Seeding & 33 & 93.4 & 223 & 59 & 44.70 & $* 39$ \\
F- value & $* *$ & $* *$ & $* *$ & 151 & $* 3$ \\
LSD (5\%) & 2.63 & 1.82 & 10.49 & 1.43 & 1.05 \\
CV & 14.7 & 7.6 & 16.3 & 10.2 & 9.2 \\
\hline
\end{tabular}

Table 4 shows that seeding depth had a significant effect on yield and yield components in wheat. Higher seedling emergence, taller plant, more spikes per square meter, increased thousand grain weight and ultimately higher grain yield was found in normal seeding condition compared to deep seeding condition. Fewer grains per spike were observed in normal seeding condition than deep seeding. As in [1] semi dwarf varieties of wheat produced more grains per spike when planted at $10 \mathrm{~cm}$ deep where moisture was not a limiting factor. An increased number of grains per spike as well as grain yield per spike 
was noted in a local wheat variety had sown under $9 \mathrm{~cm}$ deep below the soil surface [33].

Table 5. Mean effect of water stress on yield and different yield parameters of wheat

\begin{tabular}{lllllll}
\hline Treatment & EPP & PH & SPN & GPS & TGW & Y \\
\hline Irrigated & 55 & 95.7 & 303 & 56 & 46 & 5419 \\
Water stressed & 57 & 95.1 & 247 & 53 & 45 & 4091 \\
F- value & ns & ns & $* *$ & $* *$ & ns & $* *$ \\
LSD $(5 \%)$ & 2.63 & 1.82 & 10.49 & 1.43 & 1.05 & 176.39 \\
CV & 14.7 & 7.6 & 16.3 & 10.2 & 9.2 & 13.3 \\
\hline
\end{tabular}

Table 6. Interaction effect of yield and yield parameters imposed by depth and irrigation.

\begin{tabular}{|c|c|c|c|c|c|c|c|}
\hline Treatment & & EPP & PH & SPN & GPS & TGW & $\mathbf{Y}$ \\
\hline \multirow{2}{*}{ Normal Seeding } & Irrigated & 78 & 97.2 & 349 & 50 & 46.5 & 5960 \\
\hline & Water stressed & 78 & 97.6 & 306 & 48 & 45.7 & 4758 \\
\hline \multirow{2}{*}{ Deep Seeding } & Irrigated & 31 & 94.2 & 257 & 61 & 44.7 & 4878 \\
\hline & Water stressed & 36 & 92.6 & 189 & 57 & 44.7 & 3424 \\
\hline F- value & & $* *$ & $\mathrm{~ns}$ & $* *$ & $* *$ & $\mathrm{~ns}$ & $* *$ \\
\hline $\operatorname{LSD}(5 \%)$ & & 3.73 & 2.58 & 14.83 & 2.03 & 1.49 & 259.46 \\
\hline $\mathrm{CV}$ & & 14.7 & 7.6 & 16.3 & 10.2 & 9.2 & 13.3 \\
\hline
\end{tabular}

Table 7. Yield of wheat genotypes in different treatments and Schneider's stress severity index (SSSI) with average CL.

\begin{tabular}{|c|c|c|c|c|c|c|c|c|c|c|c|}
\hline \multirow{4}{*}{$\begin{array}{l}\text { Genotype } \\
\text { G 1(BARI } \\
\text { Gom 26) }\end{array}$} & \multicolumn{8}{|c|}{ Yield $(\mathrm{Kg} / \mathrm{h})^{*}$} & \multicolumn{2}{|c|}{ SSSI } & \multirow{3}{*}{ CL } \\
\hline & \multicolumn{4}{|c|}{ Normal Seeding } & \multicolumn{4}{|c|}{ Deep Seeding } & \multirow{2}{*}{ Normal seeding } & \multirow{2}{*}{ Deep Seeding } & \\
\hline & \multicolumn{2}{|c|}{ Irrigated } & \multicolumn{2}{|c|}{ Dryland } & \multicolumn{2}{|c|}{ Irrigated } & \multicolumn{2}{|c|}{ Dryland } & & & \\
\hline & 5080 & $\mathrm{bc}$ & 4700 & $a b c$ & 3960 & efghi & 4770 & $a b c$ & -0.125 & -0.505 & 7.5 \\
\hline G 2 & 5710 & $a b c$ & 5535 & $a b$ & 5084 & abcdef & 4114 & abcdef & -0.169 & -0.109 & 8.2 \\
\hline G 3 & 6547 & $a b$ & 4050 & $\mathrm{bc}$ & 4326 & defgh & 3140 & cdefghij & 0.181 & -0.026 & 7.5 \\
\hline G 4 & 7355 & a & 5305 & $\mathrm{ab}$ & 3391 & ghi & 2266 & ij & 0.079 & 0.032 & 7.6 \\
\hline G 5 & 5965 & $a b c$ & 3870 & $\mathrm{bc}$ & 3324 & hi & 2825 & efghij & 0.151 & -0.150 & 7.8 \\
\hline G 6 & 6280 & $a b c$ & 3059 & $\mathrm{c}$ & 3380 & ghi & 2010 & $\mathrm{j}$ & 0.313 & 0.105 & 5.5 \\
\hline G 7 & 5310 & $\mathrm{bc}$ & 5000 & $a b$ & 2290 & $\mathrm{i}$ & 2416 & fghij & -0.142 & -0.355 & 8.5 \\
\hline G 8 & 6105 & $a b c$ & 4280 & $\mathrm{bc}$ & 5860 & abcd & 3705 & abcdefghij & 0.099 & 0.068 & 8.8 \\
\hline G 9 & 5640 & $a b c$ & 4880 & $a b$ & 3165 & hi & 2425 & fghij & -0.065 & -0.066 & 6.8 \\
\hline G 10 & 6085 & $a b c$ & 5000 & $a b$ & 3805 & fghi & 2695 & fghij & -0.022 & -0.008 & 8.6 \\
\hline G 11 & 6390 & $a b c$ & 4135 & $\mathrm{bc}$ & 4505 & cdefgh & 2285 & hij & 0.153 & 0.193 & 9.8 \\
\hline G 12 & 6760 & $a b$ & 4225 & $\mathrm{bc}$ & 4330 & defgh & 3630 & abcdefghij & 0.175 & -0.138 & 10.5 \\
\hline G 13 & 6050 & $a b c$ & 4810 & $a b$ & 5505 & abcde & 4885 & $a b$ & 0.005 & -0.187 & 7.4 \\
\hline G 14 & 5960 & $a b c$ & 5095 & $a b$ & 6580 & $\mathrm{a}$ & 4505 & abcde & -0.055 & 0.015 & 7.7 \\
\hline G 15 & 6245 & $a b c$ & 5240 & $a b$ & 5215 & abcdef & 3295 & bcdefghij & -0.039 & 0.068 & 8.5 \\
\hline G 16 & 5965 & $a b c$ & 4640 & $a b c$ & 5650 & abcd & 5295 & $\mathrm{a}$ & 0.022 & -0.237 & 8.7 \\
\hline G 17 & 6485 & $a b$ & 5150 & $a b$ & 5400 & abcdef & 2690 & fghij & 0.006 & 0.202 & 9.8 \\
\hline G 18 & 6105 & $a b c$ & 4360 & $\mathrm{bc}$ & 5035 & abcdefg & 3920 & abcdefghi & 0.086 & -0.079 & 8.7 \\
\hline G 19 & 5860 & $a b c$ & 4435 & $a b c$ & 5950 & abcd & 4535 & abcd & 0.043 & -0.062 & 8.6 \\
\hline G 20 & 5315 & $\mathrm{bc}$ & 4910 & $\mathrm{ab}$ & 3890 & efghi & 2330 & hij & -0.124 & 0.101 & 10.2 \\
\hline G 21 & 6585 & $a b$ & 5125 & $a b$ & 5875 & abcd & 2935 & defghij & 0.022 & 0.200 & 9.3 \\
\hline G 22 & 5345 & $\mathrm{bc}$ & 5395 & $a b$ & 5850 & abcd & 3860 & abcdefghi & -0.209 & 0.040 & 9.9 \\
\hline G 23 & 5875 & $a b c$ & 5380 & $a b$ & 6450 & $a b$ & 2990 & defghij & -0.116 & 0.236 & 6.1 \\
\hline G 24 & 5940 & $a b c$ & 4580 & $a b c$ & 5950 & abcd & 4865 & $a b$ & 0.029 & -0.118 & 9.5 \\
\hline G 25 & 4655 & $\mathrm{c}$ & 3925 & $\mathrm{bc}$ & 3850 & efghi & 2645 & fghij & -0.043 & 0.013 & 10.9 \\
\hline G 26 & 5195 & $\mathrm{bc}$ & 6140 & a & 5045 & abcdefg & 3400 & bcdefghij & -0.382 & 0.026 & 10.8 \\
\hline G 27 & 5555 & $\mathrm{bc}$ & 4060 & $\mathrm{bc}$ & 5805 & abcd & 3855 & abcdefghi & 0.069 & 0.036 & 7.3 \\
\hline G 28 & 6695 & $a b$ & 5045 & $a b$ & 6210 & $a b c$ & 4065 & abcdefg & 0.046 & 0.045 & 6.8 \\
\hline G 29 & 5920 & $a b c$ & 5115 & $a b$ & 5905 & abcd & 4005 & abcdefgh & -0.064 & 0.022 & 7 \\
\hline G 30 & 5835 & $a b c$ & 5290 & $a b$ & 4755 & bcdefgh & 2365 & ghij & -0.107 & 0.203 & 10.8 \\
\hline Mean & 5960 & & 4758 & & 4878 & & 3424 & & & & \\
\hline
\end{tabular}

*Duncan's multiple range test $(\mathrm{p}=0.05)$ 
Plant establishment was counted before CRI stage when no irrigation was applied, thus table 5 revealed no variation in plant establishment in both irrigated and non-irrigated plots. Irrigation had also no effect on plant height. These non-significant variations might be due to the semi-dwarf stature of the genotypes having very little or no variation for plant height. As we do not know the nature of dwarfing genes in the genotype collection, these could possibly be GA sensitive genotypes that are reported to have no adverse effect of irrigation but reduce plant height, or possibly have favorable alleles for drought effect in a semi-dwarf background [60]. Spikes per square meter, grains per spike, thousand grain weight and yield varied due to irrigation in wheat. Similar results were recorded as in [58] where a significant effect of irrigation on 1000-grain weight was reported. Application of five irrigations at different wheat growth stages resulted in higher spike length, higher number of grains and wheat grain yield [5].

Mean interaction effect of seeding depth and irrigation in table 6 revealed that highest yield was obtained from irrigated normal seeding condition whereas lowest yield was from the non-irrigated deep sowing condition. No significant difference in yield was observed between non irrigated deep seeding conditions and irrigated normal seeding conditions. Spikes per square meter and number of grains per spike were highest (mean) in irrigated deep seeding condition. As several authors indicate that CL has a significant effect on yield and yield controlling characters, and a negative but non-significant correlation of CL found in this experiment (table 3), screening of wheat genotypes for drought and CL through deep planting might be fruitful.

G 4 was the highest yielder ( $7355 \mathrm{~kg}$ ) followed by G $12, \mathrm{G}$ 28, G 21 and G 3, respectively whereas genotype 25 (4655 $\mathrm{kg}$ ) was the lowest yielder in irrigated normal seeding condition (table 7). G $26(6140 \mathrm{~kg})$ was the maximum yielder followed by G 2, G 22, G 23 and G 4 in normal seeding in the dryland condition, whereas G $6(3059 \mathrm{~kg})$ was the lowest yielder for this environment. The highest yield under deep sowing with regular irrigation was found in $G 14$ $(6580 \mathrm{~kg})$ followed by $\mathrm{G} 23, \mathrm{G} 28, \mathrm{G} 24$ and $\mathrm{G} 19$ respectively and the lowest yielder was $\mathrm{G} 7$ in this condition. Moreover, the table revealed that G $16(5295 \mathrm{~kg})$ was the maximum yielder in the non-irrigated deep sowing condition followed by G 13, G 24 and G 19. Yield was lowest in G 6 $(2010 \mathrm{~kg})$ in non irrigated deep sowing condition.

Sixteen genotypes showed positive SSSI values for normal seeding condition, suggesting that they suffered high stress and high grain yield loss for irrigation in normal seeding. Fourteen genotypes had negative SSSI values, indicating that they experienced low stress and low grain yield loss in the same condition. Similarly, positive SSSI values for 17 genotypes in deep seeding condition indicated that they are prone to stress caused by drought induction, and also suffered greater grain yield loss. Negative SSSI values for 13 genotypes in the deep seeding condition indicate that they experience low stress in drought conditions caused by no irrigation in deep sowing.

No irrigation in the deep sowing condition imposed drought and allowed the genotype to survive in a deeper layer of soil by absorbing deep soil moisture. The survival within a deeper layer of soil must have some genotypic basis for drought tolerance. This stress tolerance is also related to coleoptiles length $[11,19,29,32,37,45,46,47,48,61$ and $62]$. Based on the higher negative value of SSSI and higher yield in deep sowing conditions the genotypes $\mathrm{G} \mathrm{16,} \mathrm{G} \mathrm{13,} \mathrm{G}$ 12, G 24, G 2, G 18, G 19 and G 3 were primarily selected for drought tolerance and will be evaluated further for advanced studies. These genotypes also have longer coleoptiles ranged from 7.4 to $10.5 \mathrm{~cm}$.

\section{Conclusion}

Considering the overall yield and other characteristics, eight genotypes have been provisionally selected at WRC, Dinajpur for further evaluation for drought tolerance and can be included in crossing blocks. The variability for CL may be partly accounted for by the unexplained variation in the relationship between CL and sowing depth. High gain from selection for increased CL requires that screening conditions are repeatable and that phenotypic differences in CL largely reflect underlying genetic factors. Large variability in seed depth arising from non uniform seed placement demonstrates the need for better sowing equipment if screening directly for $\mathrm{CL}$ in the field. Further testing is required to adapt the method for a wider range of crop types and soil conditions and testing for crops grown to maturity.

\section{Authors' Contributions}

Md. Farhad was the principle investigator (PI) who planed and set-up the experiment. Md. Abdul Hakim and Dr. Md. Ashraful Alam helped the PI to collect data, analysis the data and manuscript preparation. Dr. N. C. D. Barma had technical contribution by suggesting the plan of experiment and data collection and interpretation.

\section{Acknowledgements}

Authors thank to Dr. David Bonnett, Senior Scientist and Leader of Yield Potential Program, CIMMYT, Mexico for delivering the indoor protocol for coleoptile length study. Authors are also thankful to Harriet Benbow, a PhD student at Bristol University for language correction of the manuscript.

\section{References}

[1] Ahmad S., S. Yasmin, N. I. Hashmi and A. Qayyum (1988) Influence of seed size and Seeding depth on Performance of tall and semidwarf wheats under limited soil moisture. Pakistan J. Agric. Res. 9(1): 300-304 
[2] Allan R. E., O. A. Vogel and C. J. Peterson. (1962) Seedling emergence rate of fall sown wheat and its association with plant height and coleoptile length. Agron J. 54: 347-350. 73: $153-168$

[3] Asif M., M. Y. Mujahid, M. S. Kisana, S. Z. Mustafa and I. Ahmad, (2004) Heritability, genetic variability and path analysis of traits of spring wheat. Sarhad Journal of Agriculture, 20(1):87-91.

[4] Awan S.I., S. Niaz, M. Faisal, A. Malik and S. Ali (2007). Analysis of variability and relationship among seedling traits and plant height in semi-dwarf wheat (Triticum aestivum L.) J. Agri. Soc. Sci. 3(2):59-62 (http://www.fspublishers.org)

[5] Badaruddin Khokhar, Imtiaz Hussain and Zafar Khokhar (2010) Effect of different irrigation frequiencies on growth and yield of different wheat genotypes in sindh. Pakistan J. Agric. Res. 23( 3-4):108-112

[6] Bergale S., M. Billore, A. S. Halkar, K. N. Ruwali, S. V. S. Prasad and B. Mridulla (2001) Genetic variability, diversity and association of quantitative traits with grain yield in bread wheat. Madras Agril. Journal, 88 (7-9): 457-461.

[7] Botwright, T. L., G. J. Rebetzke, A. G. Condon and R. A. Richards (2001) Influence of variety, seed position and seed source on screening for coleoptile length in bread wheat (Triticum aestivum L.). Euphytica 119: 349-356.

[8] Brown, P. R., G. R. Singleton, C. R. Tann and I. Mock (2003) Increasing sowing depth to reduce mouse damage to winter crops; Crop Prot 22 : 653-660.

[9] Ceccarelli, S., M. T. Pegiati and F. Simeoni (1980) Relationship between coleoptile length and culm length in barley; Can J Plant Sci 60 : 687-693.

[10] Dey, N. C., M. S. Alam, A. K. Sajjan, M. A. Bhuiyan, L. Ghose, Y. Ibaraki and F. Karim, (2011). Assessing environmental and health impact of drought in the northwest Bangladesh, J. Environ. Sci. \& Natural Resources, 4(2): 89-97.

[11] Donald, C. M. and D. W. Puckridge (1975) The ecology of the wheat crop; in wheat and other temperate cereals (eds.) A Lazenby.

[12] Dwivedi, A. N., I. S. Pawar, and S. Madan (2004) Studies on variability parameters and characters association among yield and quality attributing traits in wheat. J. Crop Res., 32: 77-80.

[13] Evans, L. E. and G. M. Bhatt. (1977) Influence of seed size, protein content and cultivar on early seedling vigour in wheat. Can. J. Plant Sci., 57: 929-935.

[14] Fick, G. N. and C. O. Qualset (1976) Seedling emergence, coleoptile length, and plant height relationships in crosses of dwarf and standard-height wheats. Euphytica. 25, 679-684.

[15] Fischer, R.A. and R. Maurer, (1978) Drought resistance in spring wheat cultivars. I. Grain yield response. Aust. J. Agric. Res., 29: 897-907.

[16] Gabriela Şerban (2012) Identification of longer coleoptile mutants in an rht-blb semidwarf wheat population. Romanian. Agril. Res. 29: 17-21.

[17] Gan, Y., E. H. Stobbe and J. Moes (1992) Relative date of wheat seedling emergence and its impact on grain yield; Crop Sci., 32 : 1275-1281.
[18] Golabadi, M., A. Arzani, and S. A. M. Mirmohammadi Maibody (2006) Assessment of drought tolerance in segregating populations in durum wheat. Afr J Agric Res., $1: 162-171$.

[19] Hadjichristodoulou, A., A. Della and J. Photiades (1977) Effect of sowing depth on plant establishment, tillering capacity and other agronomic characters of cereals; J Agric Sci $89: 161-167$.

[20] Haque, M. R., M. A. Aziz, M. T. Rahman, B. Ahmed and F. Saberin. (2010) Screening of wheat genotypes for drought tolerance at vegetative stage. J. Agrofor. Environ. 4 (2): 189192.

[21] Hong Zhang and Honggang Wang. (2012) Evaluation of drought tolerance from a wheat recombination inbred line population at the early seedling growth stage. African J. Agril Res.7 (46): 6167-6172 (Available online at http://www.academicjournals.org/AJAR).

[22] IPCC (2013) Working Group I Contribution to the IPCC Fifth Assessment Report Climate Change 2013: The Physical Science Basis, Summary for Policymakers. www.climatechange2013.org/images/uploads/WGIAR5SPM_Approved27Sep2013.pdf.

[23] IRRI (2007) CropStat for windows version 7.2, International Rice Research Institute, Metro Manila, Philippines.

[24] Jennifer Pumpa, P. Martin, F. McRae and Neil Coombes (2013) Coleoptile length of wheat varieties. NSW Department of Primary Industries. Australia.REF: INT 13/1516.

[25] Kalpana Singh and R. K. Chopra. (2012) Physiology and QTL analysis of coleoptile length, a trait for drought tolerance in wheat. J. Plant Biol. 37 (2): 1-9.

[26] Kalpana Singh, S. Shukla, S. Kadam, V. K. Semwal, N. K. Singh, R. K. Chopra. (2014) Genomic regions and underlying candidate genes associated with coleoptile length under deep sowing conditions in a wheat RIL population. J. Plant Biochem. Biotechnol. 10: 1-7.

[27] Kaufmann, M. L. (1968) Coleoptile length and emergence in varieties of barley oats and wheat. Can. J. Plant Sci. 48: 357361.

[28] Khayatnezhad, M., R. Gholamin, S. Jamaati-e-Somarin, R. Zaibhi-e-Mahmoodabad (2010) Study of drought tolerance of maize genotypes using the stress tolerance index. AmEurasian J Agric Environ Sci 9:359-363.

[29] Loeppky, H., G. P. Lafond and D. B. Fowler (1989) Seeding depth in relation to plant development, winter survival, and yield of no-till winter wheat. Agron. Journal 81: 125-129.

[30] Lopez-Castaneda, C. and R. A. Richards (1994) Variation in temperate cereals in rain fed environment: III. Water use and water use efficiency; Field Crops Res. 39: 85-98.

[31] Mahdi, L., C. J. Bell, J. Ryan (1998) Establishment and yield of wheat (Triticum turgidum L.) after early sowing at various depths in a semi-arid Mediterranean environment. Field Crops Res. 58: 187-196. doi: 10.1016/S0378-4290(98)00094-X.

[32] Matsui, T., S. Inanaga, T. Shimotashiro, P. An and Y. Sugimoto (2002) Morphological characters related to varietal differences in tolerance to deep sowing in wheat. Plant Prod. Sci. 5: 169-174. 
[33] Mehmet Yagmur and Digdem Kaydan (2009) The effects of different sowing depth on grain yield and some grain yield components in wheat (Triticum aestivum L.) cultivars under dryland conditions. African J. Biotechnol.8 (2): 196-201

[34] Mohan, A., W. F. Schillinger, K. S. Gill (2013) Wheat seedling emergence from deep planting depths and its relationship with coleoptile length. PLoS ONE 8(9): e73314. doi:10.1371/journal.pone.0073314.

[35] Monneveux, P., and S. C. Jing Rand Misra (2012) Phenotyping for drought adaptation in whea tusing physiological traits. Front. Physio. 3:429.doi: 10.3389/ fphys.2012.00429.

[36] Multibase 2015: Excel Add-ins for PCA and PLS, (2014) NumericalDynamics.com/DownLoad2.html.

[37] Murray, G. M. and J. Kuiper (1988) Emergence of wheat may bereduced by seed weather damage and azole fungicide and is related to coleoptile length; Aust. J. Exp. Agric. 28 : 253-261.

[38] Nebreda, I. M. and P. C. Parodi (1977) Effect of seed type on coleoptile length and weight in triticale, $X$ Triticosecale Wittmack. Cereal Res. Communications 5: 387-398.

[39] Nouri, A., A. Etminan, A. Jaime, T. da Silva and R. Mohammadi (2011) Assessment of yield, yield-related traits and drought tolerance of durum wheat genotypes (Triticum turjidum var. durum Desf.). Aust. J. Crop Sci. 5:8-16.

[40] O'Sullivan, P. A., G. M. Weiss and D. Friesen (1985) Tolerance of spring wheat (Triticum aestivum L.) to trifluralin deep-incorporated in the autumn or spring; Weed Res 25 : 275-280.

[41] Onofri A. (2007) Routine statistical analyses of field experiments by using an Excel extension. Proceedings 6th National Conference Italian Biometric Society: "La statistica nelle scienze della vita e dell'ambiente", Pisa, 20-22 June 2007, 93-96.

[42] Ouk, M., J. Basnayake, M. Tsubo, S. Fukai, K. Fischer, M. Cooper and H. Nesbitt (2006) Use of drought response index for identification of drought tolerant genotypes in rainfed lowland rice. Field Crops Res. 99:48-58.

[43] Pantuwan, G., S. Fukai, M. Cooper, S. Rajatasereekul and J. C. O'Toole (2002) Yield response of rice (Oryza sativa L.) genotypes to different types of drought under rainfed lowlands. I. Grain yield and yield components. Field Crops Res.

[44] Radford, B. J. (1987) Effect of constant and fluctuating temperature regimes and seed source on the coleoptile length of tall and semi dwarf wheats. Aust. J. Exp. Agric. 27: 113117.

[45] Rebetzke, G. J., S. E. Bruce and J. A. Kirkegarrd (2005) Longer coleoptiles improve emergence through crop residues to increase seedling number and biomass in wheat; Plant Soil $272: 87-100$.

[46] Rebetzke, G. J., M. H. Ellis, D. G. Bonnett and R. A. Richards (2007a) Molecular mapping of genes for coleoptile growth in bread wheat (Triticum aestivum L.); Theor Appl Genet 114 : 1173-1183.

[47] Rebetzke, G. J., R.. A. Richards, N. A. Fettell, M. Long, A. G. Condon, R. I. Forrester and T. L. Botwright. (2007b)
Genotypic increases in coleoptile length improves stand establishment, vigour and grain yield of deep-sown wheat; Field Crops Res. 1: 10-23

[48] Rebetzke, G. J., R. A. Richards, V. M. Ficher and B. J. Mickelson. (1999) Breeding long coleoptile, reduced height wheats. Euphytica 106: 159-168.

[49] Reithmuller, G. P. (1990) Machinery for improved crop establishment in Western Australia. In 'Agricultural Engineering Conference1990' pp. 40-45. (Institute of Engineers: Australia).

[50] Schillinger, W. F., E. Donaldson, R. E. Allan and S. S. Jones (1998) Winter wheat seedling emergence from deep sowing depth; Agron J 90 : 582-586.

[51] Schneider, K. A., R. Rosales-Serna, F. Ibarra-Perez, B. Cazares-Enriquez, J. A. Acosta-Gallegos, P. Ramirez-Vallejo, N. Wassini and J. D. Kelly (1997) Improving common bean performance under drought stress. Crop Sci 37:43-50.

[52] Singh, B. U., K. V. Rao and H. C. Sharma (2011) Comparison of selection indices to identify sorghum genotypes resistant to the spotted stemborer Chilo partellus (Lepidoptera: Noctuidae). Int. J. Trop. Insect Sci. 31:38-51.

[53] Sio-Se Mardeh, A., A. Ahmadi, K. Poustini and V. Mohammadi (2006) Evaluation of drought resistance indices under various environmental conditions. Field Crops Res. 98:222-229.

[54] Slafer, G. A., J. L. Araus, C. Royo and L. F. G. DelMoral (2005) Promising eco-physiological traits for genetic improvement of cereal yields in Mediterranean environments; Ann. App. Biol. $146: 61-70$.

[55] Stocktom, R. D., E. G. Krenzer, J. Solie and M. E. Payton (1996) Stand establishment of winter wheat in Oklahoma; A survey; J Prod Agric 9: 571-575.

[56] Stoddard, F. L. (1999). Variation in grain mass, grain nitrogen and starch B-granule content within wheat heads. Cereals Chem. 76: 139-144.

[57] Talebi, R., F. Fayazl and A. M. Naji (2009) Effective selection criteria for assessing drought stress tolerance in durum wheat (Triticum durum Desf.). Gen. Appl. Plant Physiol. 35:64-74.

[58] Trethowan, R., R. Singh, J. Huerta-Espino, Crossa, and M. Van Ginkel (2001) Coleoptile length variation of nearisogenic Rht lines of modern CIMMYT bread and durum wheats. Field Crops Res. 70: 167-176.

[59] Wajid, A., A. Hussain, M. M. Ahmed and M. Waris (2002) Influence of sowing date and irrigation levels on growth and grain yield of wheat. Pak. J. Agric. Sci. 39 (1): 22-24.

[60] Wang, J., S. C. Chapman, D. G. Bonnett and G. J. Rebetzke (2009) Simultaneous selection of major and minor genes: use of QTL to increase selection efficiency of coleoptile length of wheat (Triticum aestivum L.). Theoretical and Applied Genetics 119: 65-74. doi:10.1007/s00122-009-1017-2.

[61] Whan, B. R. (1976a) The emergence of semidwarf and standard wheats, and its association with coleoptile length. Aust. J Exp. Agril. Animal Husb. 16: 411-416.

[62] Whan, B. R. (1976b) The association between coleoptile length and culm length in semidwarf and standard wheats; J. Aust .Inst. Agri. Sci. 42 : 194-196. 
[63] WRC Annual Report 2011-2012 (2012), Wheat Research Centre, Bangladesh Agricultural Research Institute (BARI), Nashipur, Dinajpur, Bangladesh.
[64] Yashu, T. and K. Fujii (1979) Studies on the elongation of mesocotyle and coleoptile length in gramineouss crops. I. On the elongation ratio of mesocotyle and coleoptile; Jpn J. Crop Sci. 48: 356-364. 